Quim. Nova, Vol. 32, No. 1, 48-50, 2009

\title{
FIRST SECONDARY METABOLITES FROM Herissantia crispa L (Brizicky) AND THE TOXICITY ACTIVITY AGAINST Artemia salina LEACH.
}

\author{
Danielly Albuquerque da Costa, Wemerson Neves Matias, Igara Oliveira Lima, Aline Lira Xavier, Vivian Bruna Machado \\ Costa, Margareth de Fátima Formiga Melo Diniz, Maria de Fátima Agra, Leônia Maria Batista and Maria de Fátima \\ Vanderlei de Souza* \\ Laboratório de Tecnologia Farmacêutica "Prof. Delby Fernandes de Medeiros", Centro de Ciências da Saúde, Universidade Federal \\ da Paraíba, CP 5009, 58051-970 João Pessoa - PB, Brasil

\section{Davi Antas e Silva} \\ Departamento de Química, Universidade Federal Rural de Pernambuco, Unidade Acadêmica de Serra Talhada, 56900-000 Serra \\ Talhada - PE, Brasil
}

Recebido em 26/11/07; aceito em 15/7/08; publicado na web em 5/12/08

\begin{abstract}
FIRST SECONDARY METABOLITES FROM Herissantia crispa L (Brizicky) AND THE TOXICITY ACTIVITY AGAINST Artemia salina Leach.The phytochemical investigation of Herissantia crispa led to the isolation of seven compounds, identified as: sitosterol 3-O- $\beta$-D-glucopyranoside, stigmasterol 3-O- $\beta$-D-glucopyranoside, 3,5,7,4'-tetrahydroxyflavone (kaempferol), 3,5,7,3',4'-pentahydroxyflavone (quercetin), unpublished in the genus Herissantia, besides $\beta$-sitosterol, kaempferol 3-O- $\beta$-D-(6"- $E$ $p$-coumaroil) (tiliroside) glucopyranoside and kaempferol 3,7-di- $O$ - $\alpha$-L-ramnopyranoside (lespedin), described for the first time in the species. The structural determination of the compounds was made by means of spectroscopy methods such as Infrared Spectroscopy, ${ }^{1} \mathrm{H}$ and ${ }^{13} \mathrm{C}$ Nuclear Magnetic Resonance, with the aid of two dimensional techniques, and by comparison with literature data. The toxicity activity of the $\mathrm{MeOH}$ extract and lespedin on Artemia salina Leach. was also carried out.
\end{abstract}

Keywords: Malvaceae; Herissantia crispa; Artemia salina.

\section{INTRODUCTION}

Malvaceae is a widespread family with about 243 genera and 4225 species, ${ }^{1}$ particularly distributed in tropical areas. ${ }^{2}$ There are many reports in the literature regarding the use of Malvaceae species in traditional medicine. Some of these uses include snakebites, ${ }^{3}$ asthma, ${ }^{4}$ diuretic, in treatment of rheumatism and gastrointestinal disorders, ${ }^{5,6}$ among others. Chemical studies about the secondary metabolites from Malvaceae have described the occurrence of triterpenes, ${ }^{7}$ flavonoids,,${ }^{8,9}$ essential oils, ${ }^{10}$ sesquiterpenelactones ${ }^{11}$ and fatty acids. ${ }^{12-15}$

The genus Herissantia is constituted by six species, found in the tropical America, particularly in Antilles, Mexico and South America. ${ }^{16}$ However, only Herissantia crispa is widespread, being reported from The United States to Argentina. ${ }^{17}$ In our phytochemical and pharmacological studies with Malvaceae family, we have described the isolation of a great variety of natural compounds from Herissantia and other genera. From Sida galheirensis Ulbr., we isolated a 3-methoxyflavonol, a phaephorbide a, a coumarin, a benzoic acid derivative, two sterol glucosides ( $\beta$-sitosterol and stigmasterol), two flavones (luteolin and apigenin) and two flavonol glucosides (tiliroside and luteolin 7-glucoside). The EtOAc and $\mathrm{BuOH}$ extracts from $S$. galheirensis showed a good antioxidant activity using the free radical scaveging assay. ${ }^{18}$ The species Bakeridesia pikelli MONTEIRO provided a nonglycosyl and two glycosyl steroids, vanillic acid and two flavonol glycosides (kaemfperol-3- $O$ - $\beta$-D-glucopyranoside and tiliroside). The latter compound showed relaxant activity on guinea-pig ileum. ${ }^{19}$ From Herissantia tiubae (K. Schum) Brizicky four triterpenes (frideline, lupeol, cycloartenol and cycloeucalenol), a steroid ( $\beta$-sitosterol) and four phenolic compounds (a benzoic acid derivative, a coumarin and three flavonol glycosides, kaempferol 7-O- $\alpha$-L-rhamnopyranoside,

\footnotetext{
*e-mail: mfvanderlei@ltf.ufpb.br
}

lespedin and tiliroside) were isolated. Cycloeucalenol and cycloartenol also showed a relaxant effect in the guinea-pig ileum. ${ }^{20}$ The highly oxygenated flavonoid 4',5-dihydroxy-3,6,7,8,3'-pentamethoxyflavone played a role in modulating the bacterial resistance to some antibiotics. ${ }^{21}$ Preliminary studies carried out with lespedin revealed a relaxing activity on superior mesenteric artery, which could be considered as an important result in the cardiovascular field. ${ }^{9}$ Based on the above evidences concerning Malvaceae and the genus Herissantia, we focused our study on Herissantia crispa L. (Brizicky), an unstudied species which is subject of our continuous investigations in discovering potential natural products with biological activities.

Plants have been used for many years as medicines by population, providing good sources of pharmacologically actives substances and improving the therapeutic arsenal. However, many plants are known to be toxic. For this reason, researches are carried out in order to determine their pharmacological action and toxicity. ${ }^{22}$

There is a currently tendency to call for substituting the use of laboratory animals in toxicological tests, due to the high cost and the animal suffering caused by these tests. Alternative methods include procedures that could replace experiments performed with animals, reduce the number of animals used in each test, or refine the existing methodology in order to lessen pain and stress. ${ }^{22}$

Artemia salina L., the brine shrimp, is an invertebrate component of the fauna of saline aquatic and marine ecosystems. It can be used in a laboratory bioassay in order to determine toxicity through the estimation of the medium lethal concentration $\left(\mathrm{LC}_{50}\right)$. This method has been used in research in order to evaluate toxicity and biological actions as a screening method mainly for products of plant origin. One basic premise here is that toxicology is simply pharmacology at higher dose; thus, if we find toxic compounds, a lower, non-toxic dose might elicit a useful, pharmacological perturbation on a physiologic system. ${ }^{23}$

In the present study we describe the isolation of the first compoun- 
ds from $H$. crispa and also the evaluation of the cytotoxic activity of its $\mathrm{MeOH}$ extract and lespedin on Artemia salina Leach.

\section{EXPERIMENTAL}

\section{General procedures}

NMR spectra were measured in $\mathrm{CDCl}_{3} \mathrm{CD}_{3} \mathrm{OD}$ and pyridine- $d_{5}$ and recorded on a Mercury Varian instrument operating at 200 and $50 \mathrm{MHz}$ for ${ }^{1} \mathrm{H}$ and ${ }^{13} \mathrm{C}$, respectively. The solvent signal was used as internal standard. IR spectra were measured on a Perkin-Elmer, FTIR-1750 spectrometer in $\mathrm{KBr}$ pellets. Chromatography columns were carried out on silica gel (Merck) and Sephadex LH-20 (Pharmacia, Upsala-Sweden). TLC were performed on silica gel $\mathrm{PF}_{254}$ plates and the spots were visualized under UV light (244 and $366 \mathrm{~nm}$ ) and by spraying with $5 \% \mathrm{FeCl}_{3}$ reagent.

\section{Plant material}

The whole plant of $H$. crispa was collected in Pedra da Boca, in the city of Araruna, state of Paraíba, on September 2003. The botanical identification was made by Dr. M. de F. Agra and a voucher specimen was deposited at the Herbarium Prof. Lauro Pires Xavier (JPB), Universidade Federal da Paraíba (Voucher No. 6237).

\section{Extraction and isolation}

Dried and powdered whole plant $(7 \mathrm{~kg})$ of $H$. crispa was exhaustively extracted with methanol at room temperature. The solvent from the combined extract was evaporated to dryness under reduced pressure to yield $237 \mathrm{~g}$ of a dark solid. This residue was suspended in methanol: $\mathrm{H}_{2} \mathrm{O}(7: 3)$ and successively partitioned with hexane, $\mathrm{CHCl}_{3}$, EtOAc and butanol. The hexane extract $(11 \mathrm{~g})$ was submitted to column chromatography using silica gel as stationary phase and eluted with hexane, EtOAc and $\mathrm{MeOH}$ with increasing polarity. In this process, fractions of $50 \mathrm{~mL}$ were collected. Fractions 70-75 were analysed by TLC, combined and recrystallized with $\mathrm{CHCl}_{3}$, yielding $\beta$-sitosterol (1) (720 mg). The chloroform extract was also chromatographed on silica gel 60 column using hexane, $\mathrm{CHCl}_{3}$ and $\mathrm{MeOH}$ (fractions of $70 \mathrm{~mL}$ ). After TLC analysis, fractions 120-125 were gathered and then recrystallized with $\mathrm{CHCl}_{3}: \mathrm{MeOH}(1: 1)$, yielding a mixture of sitosterol 3-O- $\beta$-D-glucopyranoside (2) and stigmasterol 3-O- $\beta$-Dglucopyranoside (3) (300 mg). The ethyl acetate extract (4.58 g) was subjected to a Sephadex LH-20 gel column eluted with MeOH (fractions of $15 \mathrm{~mL}$ ). Fractions 11-18, 19-20 and 21-22 were combined after observation on TLC $\left(\mathrm{SiO}_{2}, \mathrm{CHCl}_{3}: \mathrm{MeOH}, 5 \% \mathrm{FeCl}_{3}\right)$ and led to the isolation of kaempferol 3-O- $\beta$-D-(6"- $E$ - $p$-coumaroil) glucopyranoside (tiliroside) $(\mathbf{4}, 350 \mathrm{mg}), 3,5,7,4$ '-tetrahydroxyflavone $(\mathbf{5})(80 \mathrm{mg})$ and $3,5,7,3^{\prime}, 4^{\prime}$-pentahydroxyflavone (6) (20 mg), respectively. The butanol extract was applied to a Sephadex $\mathrm{LH}-20$ column eluted with $\mathrm{MeOH}$, affording 18 fractions of $15 \mathrm{~mL}$. Pooled fractions 11-16 gave pure kaempferol 3,7-di- $O$ - $\alpha$-L-ramnopyranoside (7) (1.93 g) (Figure 1).

\section{Bioassay with Artemia salina - Determination of lethal concentration $50 \%\left(\mathbf{L D}_{50}\right)$}

Brine Shrimp eggs (Artemia salina) were obtained from LabetoxLTF-UFPB. They were hatched in natural seawater and incubated for $24 \mathrm{~h}$, at $28^{\circ} \mathrm{C}$, with continuous side illumination ( $40 \mathrm{~W}$ lamp). The nauplii did not receive food, because they are fed in their yolksac in $48 \mathrm{~h}^{24}$ and the larvae are viable for $36-48 \mathrm{~h} .{ }^{25}$ After hatching, 10-15 nauplii were collected and put in tubes containing different concentrations of the $\mathrm{MeOH}$ extract (MeOHE) or kaempferol 3,7-
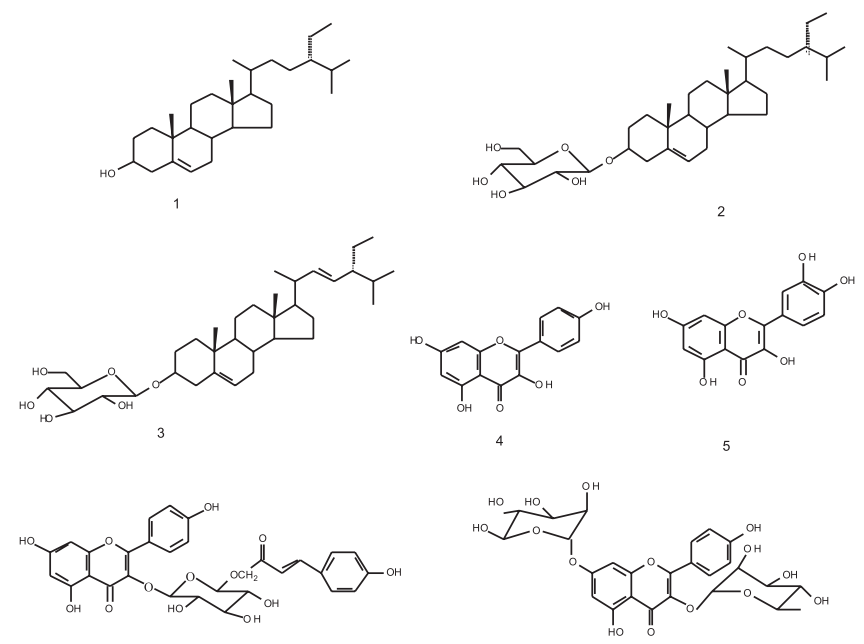

6

Figure 1. Chemical constituents isolated from H. crispa

di- $O$ - $\alpha$-L-raminopyranoside (lespedin) (five dilutions, $10-1000 \mu \mathrm{g} /$ $\mathrm{mL}$ ). Three replications were used for each concentration and the experiment was repeated twice. A parallel series of tests with the blank control was always conducted. The method used was that of McLaughlin. ${ }^{26}$ The lethal concentration for $50 \%$ mortality after $24 \mathrm{~h}$ of exposure $\left(\mathrm{LC}_{50}\right)$ was determined using the probit method. As the measure of toxicity of the extract, $\mathrm{LC}_{50}$ value lower than $1000 \mu \mathrm{g}$ / $\mathrm{mL}$ is considered bioactive. ${ }^{27}$

3,7-di- $\boldsymbol{O}$ - $\alpha$-L-ramnopyranoside (lespedin) (7): IR (KBr) $\bar{v}_{\text {ma }}$ $3374 \mathrm{~cm}^{-1} 2981$ e $2937 \mathrm{~cm}^{-1}, 1659 \mathrm{~cm}^{-1} 1602$ and 1449; ${ }^{1} \mathrm{H}$ NMR [(200 MHz, CD 3 OD, $\delta(\mathrm{ppm}), J(\mathrm{~Hz})]: 7.72\left(d, J=8.8 \mathrm{~Hz}, \mathrm{H}-2^{\prime}, 6^{\prime}\right)$, $6.90\left(d, J=8.8 \mathrm{~Hz}, \mathrm{H}-3^{\prime}, 5^{\prime}\right), 6.63(d, J=2.1 \mathrm{~Hz}, \mathrm{H}-8), 6.38(d, J=$ $2.1 \mathrm{~Hz}, \mathrm{H}-6), 5.55$ ( $\left.d, J=1.6 \mathrm{~Hz}, \mathrm{H}-1^{\prime \prime}\right), 5.36$ ( $\left.d, J=1.6 \mathrm{~Hz}, \mathrm{H}-1^{\prime \prime \prime}\right)$, 4.26-3.30 ( $\left.m, \mathrm{H}-2^{\prime \prime}-5^{\prime \prime}, \mathrm{H}-2^{\prime \prime \prime}-5^{\prime \prime \prime}\right), 1.26$ ( $\left.d, J=5.8 \mathrm{~Hz}, \mathrm{H}-6^{\prime \prime}\right), 0.93$ $\left(d, J=5.6 \mathrm{~Hz}, \mathrm{H}-6^{\prime \prime \prime}\right)$; [(50 MHz, $\left.\mathrm{CDCl}_{3}, \delta(\mathrm{ppm})\right]: 179.63(\mathrm{C}-4)$, 163.41 (C-7), 162.85 (C-5), 161.69 (C-4'), 159.69 (C-9), 157.90 (C2), 136.39 (C-3), 131.96 (C-2',6'), 122.28 (C-1'), $116.56\left(\mathrm{C}-3^{\prime}-5^{\prime}\right)$, 107.45 (C-10), 103.42 (C-1"'), 100.47 (C-1" $), 99.73$ (C-6), 95.57 (C8), $73.54\left(\mathrm{C}-4^{\prime \prime}\right), 73.13$ (C-4"'), 72.03 (C-3", $\left.3^{\prime \prime \prime}, 5^{\prime \prime \prime}\right), 71.87$ (C-2'"), $71.62\left(\mathrm{C}-2^{\prime \prime}\right), 71.22\left(\mathrm{C}-5^{\prime \prime}\right), 18.09$ (C-6"), $17.66\left(\mathrm{C}-6^{\prime \prime \prime}\right)$.

\section{RESULTS AND DISCUSSION}

The structural assignments of compounds 1-7 were made based on the spectral analysis and are in good agreement with those reported in the literature. Thus, their structures were identified as $\beta$-sitosterol (1) ${ }^{26}$ sitosterol 3-O- $\beta$-D-glucopyranoside $(2),{ }^{28}$ stigmasterol 3-O- $\beta$ D-glucopyranoside (3), ${ }^{28}$ kaempferol 3-O- $\beta$-D-(6"- $E$-p-coumaroil) glucopyranoside (4) (tiliroside), ${ }^{29}$ 3,5,7,4' -tetrahydroxyflavone (kaempferol) (5) ${ }^{30}$ and 3,5,7,3', 4' -pentahydroxyflavone (quercetin) (6) ${ }^{31}$ Compounds 2, 3, 5 and $\mathbf{6}$ are being reported here for the first time in the genus Herissantia. Compound $\mathbf{4}$ (tiliroside) was previously isolated from Malvaceae species, for example Herissantia tiubae, ${ }^{8}$ Sida galheirensis ${ }^{18}$ and Bakeridesia pickelli. ${ }^{19}$ The isolation of compound 7 was also reported from the leaves of $H$. tiubae. ${ }^{9}$

In this work, we examined the biological activities of the MeOHE and lespedin on the bioassay of A. salina. This bioassay was made twice and the lethal concentration $\left(\mathrm{LC}_{50}\right)$ was the result of the mean of these two tests. MeOHE and lespedin showed $\mathrm{LC}_{50}=629.24 \mu \mathrm{g} / \mathrm{mL}$ (Figure 2) and $\mathrm{LC}_{50}=611.25 \mu \mathrm{g} / \mathrm{mL}$ (Figure 3); they were considered bioactive due to the fact that their capacity to kill $50 \%$ of larvae is lower than $1000 \mu \mathrm{g} / \mathrm{mL}$. The $\mathrm{LC}_{50}$ of lespedin was similar to those 


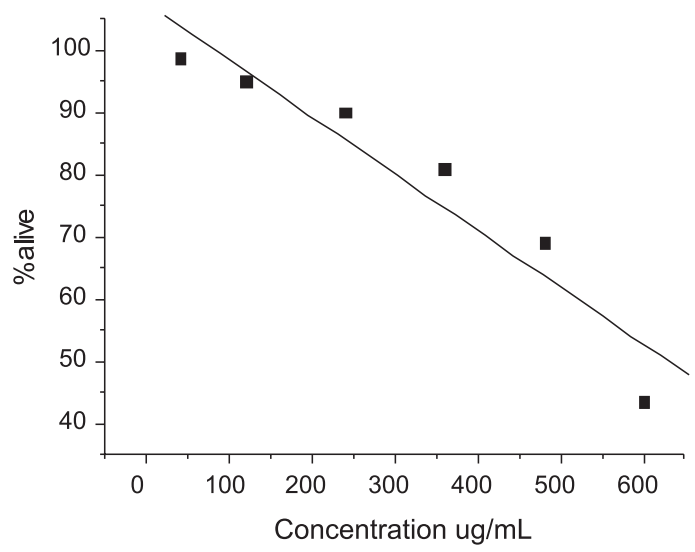

Figure 2. Effect of MeOHE of H. crispa on bioassay of A. salina

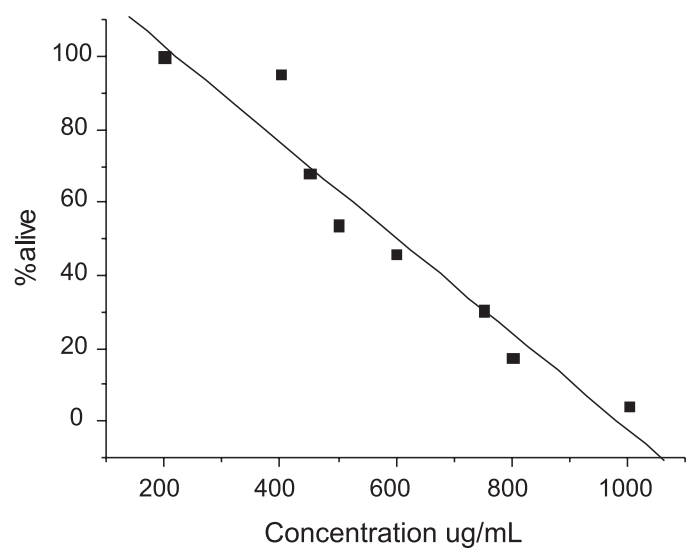

Figure 3. Effect of lespedin of H. crispa on bioassay of A. salina

of the MeOHE; then, it is possible that this compound contribute in a broad range to the overall bioactivity of the extract. Further studies on the MeOHE of H. crispa will be carried out to better define the spectrum of its biological activity and correlate it to the chemical composition of its extracts.

The result reported here not only provided an insight into the toxic nature of the extract, but also an opportunity for selection of a bioactive extract for initial fractionation and further studies in toxicological and pharmacological assays. Thus, more specific studies will be done to investigate the toxicity of the MeOHE and lespedin of $H$. crispa in animal models.

\section{REFERENCES}

1. http://www.mobot.mobot.org, accessed in May 2007.

2. Heywood, V. H.; Flowering plants of world, Batsford Ltd: London, 1993.

3. Otero, R.; Núnez, V.; Barona, J.; Fonnegra, R.; Jiménez, S. L.; Osorio, R. G.; Saldarriaga, M.; Díaz, A.; J. Ethnopharmacol. 2000, 73, 233.

4. Franzotti, E. M.; Santos, C. V. F.; Rodrigues, H. M. S. L.; Mourão, R.
H. V.; Andrade, M. R.; Antoniolli, A. R.; J. Ethnopharmacol. 2000, 72, 273.

5. Schultz, A. R.; Introdução ao estudo da botânica sistemática, $3^{\mathrm{a}}$ ed. Globo: Porto Alegre, 1968.

6. Yesilada, E.; Gürbüz, I. A.; Compilations of the studies on the antiulcerogenic effects of medicinal plants. Recent progress in medicinal plants, SCI Tech Publishing LLC: Houston, 2002.

7. Ahmed, Z.; Kazmi, S. N. H.; Malik, A.; J. Nat. Prod. 1990 53, 1342.

8. Silva D. A.; Chaves M. C. O.; Costa, D. A.; Moraes, M. R. R.; Nóbrega, F. B. P.; Souza, M. F. V.; Pharm. Biol. 2005, 43, 197.

9. Silva, D. A.; Costa, D. A.; Silva, D. F.; Souza, M. F. V.; Agra, M. F.; Medeiros, I. A.; Barbosa-Filho, J. M.; Braz-Filho, R.; Rev. Bras. Farmacogn. 2005, 15, 23.

10. Ames, J. M.; Macleod, G.; Phytochemistry 1990, 29, 1201.

11. Sharma, P. V.; Ahmad, Z. A.; Phytochemistry 1989, 28, 3525.

12. Carmody, D. R.; Dejong, W.; Smith, T. R.; Oil \& Soap 1945, October, 263.

13. Vickery, J. R.; JAOCS 1980, February, 87.

14. Schimid, K. M.; Patterson, G. W.; Phytochemistry 1988, 27, 2831.

15. Nakatani M.; Fukunaga, Y.; Hase, T.; Phytochemistry 1986, 25, 449.

16. Fryxell, P. A.; Britonia 1997, 49, 204.

17. Fryxell, P. A.; Flora del Bajio y de regiones adyacentes 1993, 16, 1.

18. Silva, D. A.; Sarmento, T. M. S.; Lins, A. C. S.; Costa, D. A.; Cavalcante, J. M. S.; Matias. W. N.; Souza, M. F. V.; Braz-Filho, R.; Quim. Nova 2006, 29, 1250.

19. Costa, D. A.; Silva, D. A.; Cavalcanti, A. C.; Medeiros, M. A. A.; Lima, J. T.; Cavalcante, J. M. S.; Silva, B. A.; Agra, M. F.; Souza, M. F. V.; Quim. Nova 2007, 30, 901.

20. Gomes, A. Y. S.; Souza, M. F. V.; Cortes, S. F.; Lemos, V. S.; Planta Med. 2005, 71, 1025.

21. Silva, D. A.; Falcão-Silva, V. S.; Gomes, A. Y. S.; Costa, D. A.; Lemos, V. S.; Agra, M. F.; Braz-Filho, R.; Siqueira-Junior, J. P.; Souza, M. F. V.; Pharm. Biol. 2009, 47, 00.

22. Parra, A. L.; Yhebra, R. S.; Sardiñas, I. G.; Buela, L. I.; Phytomedicine 2001, 8, 395 .

23. Pimentel Montanher, A. B.; Pizzolatti, M. G.; Costa Brighente, I. M.; Acta. Farm. Bonaerense 2002, 21, 175.

24. Carballo, J. L.; Hermanández-Inda, Z. L.; Pérez, P.; García-Grávalos, M. D.; BMC Biotechnology 2002, 2, 17.

25. Acey, R. A.; Bailey, S.; Healy, P.; Jo, C.; Unger, T. F.; Hudson, R. A.; Biophy. Res. Comm. 2002, 299, 659.

26. Mclaughlin, J. L.; Rogers, L. L.; Anderson, J. E.; Drug Information J. 1998, 32, 513.

27. Meyer, B. N.; Ferrigni, N. R.; Putnam, J. E.; Jacobsen, L. B.; Nichols, D. E.; Mec Laughlin, J. L.; Planta Med. 1982, 45, 31.

28. Kojima, H.; Sato, N.; Hatano, A.; Ogura, H.; Phytochemistry 1990, 29 , 2351.

29. Kaouadji, M.; Doucoré, A.; Mariotte, A. M.; Chulia, A. J.; Thomasson, F.; Phytochemistry 1990, 29, 1283.

30. Pizzolatti, M. G.; Cunha Jr., A.; Szpoganicz, B.; Sousa, E; Braz-Filho, R.; Schripsema, J.; Quim. Nova 2003, 26, 466.

31. Agrawal, P. K.; Carbon-13 NMR of Flavonoids: Studies in Organic Chemistry 39, Elsevier: Lucknov, 1989. 